\title{
Expression of Human Intestinal mRNA Transcripts during Development: Analysis by a Semiquantitative RNA Polymerase Chain Reaction Method
}

\author{
YANGXI WANG, CLARE HARVEY, MONIQUE ROUSSET, AND DALLAS M. SWALLOW \\ Medical Research Council Human Biochemical Genetics Unit, Galton Laboratory, University \\ College London, London NWI 2HE, United Kingdom [Y.W., C.H. D.M.S. l, and INSERM Unit \\ 178, 94807 Villejuif Cedex, France [M.R.]
} \begin{abstract}
To study the relative expression of lactase, sucrase-
isomaltase, dipeptidyl peptidase IV, and the $\mathrm{Na}^{+}$. samples of human tissue, we have developed and validated a very simple semiquantitative RNA polymerase chain reaction method that can be used on as little as $5-10 \mathrm{mg}$ of tissue. Here we report the use of this method to study the expression of these genes at different stages of development, in different tissues and in different parts of the intestine, in comparison with another intestinal marker, the colon-specific transcript of carbonic anhydrase 1. Lactase, sucrase-isomaltase, and the $\mathrm{Na}^{+}$-dependent glucose transporter mRNA are expressed predominantly in the small intestine, although lactase mRNA is expressed at a very low level in fetuses. Dipeptidyl peptidase IV mRNA shows a much wider tissue distribution. Sucrase-isomaltase and
\end{abstract}

The brush-border membrane of mammalian small intestinal enterocytes carries a characteristic series of hydrolases and transporters (1-4). These proteins show changes in expression during development (5-8), along the length of the intestine (9), and also along the cryptvillus axis of the villi (10). Certain of these proteins, e.g. sucrase-isomaltase (EC 3.2.1.10/3.2.1.48) and lactasephlorizin hydrolase (EC 3.2.1.23/3.2.1.62), are believed to show a very restricted tissue distribution $(11,12)$, whereas others, in particular peptidases such as dipeptidyl peptidase IV (EC 3.4.14.5), appear to be expressed in many tissues (13-15).

Although a certain amount of information is available as to the expression of these genes at the mRNA level in

Received January 18, 1994; accepted May 3, 1994.

Correspondence: D. M. Swallow, MRC Human Biochemical Genetics Unit, Galton Laboratory, UCL, Wolfson House, 4 Stephenson Way, London NW1 2HE, United Kingdom.

Supported in part by a grant from NATO $(0789 / 88)$. dipeptidyl peptidase IV mRNA are present at high levels in fetal colon and also at surprisingly high levels in adult colon. Lactase mRNA, on the other hand, is present at very low levels in fetal colon and is not detectable at all in adult colon. The $\mathrm{Na}^{+}$-dependent glucose transporter mRNA in contrast is expressed at higher levels in the adult colon than in the fetal colon. This is also the case for the carbonic anhydrase 1 transcript, although this transcript is not expressed in the small intestine. Thus, each of these genes shows different developmental and cell-specific regulation. (Pediatr Res 36: 514-521, 1994)

\section{Abbreviations}

PCR, polymerase chain reaction dNTP, nucleotide triphosphates RT mix, reverse transcription mixture

the small intestine $(12,16-22)$, information is limited, particularly in humans, concerning their relative expression at different stages of development and in different parts of the intestine. It is hard to compare the results obtained in different studies on different samples by different methods. It is in any case difficult to obtain suitable human tissue in large enough quantities for multiple gene products to be assayed using the same material. In this study, we have developed an RNA PCR method for the semiquantitative assessment of the level of multiple mRNA transcripts in the same small tissue sample.

Although RNA PCR is a powerful technique, especially for the detection and amplification of rare mRNA transcripts, it is more difficult to quantify the amounts of mRNA present in the starting material because the amplification is an exponential process $(23,24)$. Factors that influence the efficiency of the reverse transcription of RNA into cDNA and the subsequent PCR amplification will therefore dramatically affect the yield of PCR prod- 
uct and thus the quantitation. Although it is possible to make use of control constructs in the same tube that give rise to a PCR product that can be distinguished from the target cDNA (25), this is particularly cumbersome when multiple gene transcripts are to be quantified at the same time, and the control constructs corresponding to each gene should in any case be made of RNA if both the transcription and PCR steps are to be controlled. Here we describe a much simpler modification of the RNA PCR method. We have optimized the conditions for the reverse transcription and used random hexamers to prime the synthesis of a representative pool of cDNA from each sample. A number of different specific PCR amplifications were carried out using each cDNA pool.

Using this method, we have reexamined the expression of several "brush-border" genes in the small and large intestine of human fetuses and adults and their tissue distribution at the mRNA level. Analysis of the mRNA expression in the colon was of particular interest in view of the many reports concerning changes in the expression of these genes in colon cancer (26-29) and the known transient expression of certain enterocytic markers in fetal colon (30-33). Because the colon-specific transcript of carbonic anhydrase 1 (EC 4.2.1.1) is one of the very few colon-specific markers available (34), it was of interest to compare the expression of this mRNA with those of the brush-border proteins.

\section{METHODS}

Tissues. Full-thickness samples of mid small intestine and colon from 14 fetuses of 9-18 wk gestational age (weeks postconception) were obtained from the Medical Research Council (London, UK) Tissue Bank. Both proximal and distal colon were tested in one case (a 17-wk fetus), and in all other cases proximal colon only was obtained. Three full-thickness midjejunal samples were taken from adult organ transplant donors, two fullthickness distal jejunal specimens were obtained at surgery, and four duodenal pinch biopsy samples (corresponding to the full-thickness mucosal layer, omitting muscle) were obtained by endoscopy and were all shown by lactase assay to be from lactase-persistent individuals.
Four distal colon samples were taken from adult organ donors, and the mucosal layer, scraped free from the muscle, was used.

Samples of tissues other than the intestine (heart, lung, liver, kidney, spleen) were obtained at surgery, from organ transplant donors, and at postmortem within $24 \mathrm{~h}$ of death. The fetal tissues were from the Medical Research Council Tissue Bank and included placenta, brain, muscle, thymus, stomach, thyroid, and adrenals, each from different individuals (12-18 wk of gestational age). The adult tissues were obtained from a variety of centers over several years.

All the tissue samples were flash frozen in liquid nitrogen, when possible within approximately $1 \mathrm{~h}$ of removal from the donor, placed in small plastic bags to exclude as much air as possible, and then stored at $-70^{\circ} \mathrm{C}$ until used.

Total RNA preparation. Total RNA was isolated from flash-frozen tissues using the guanidinium thiocyanatephenol-chloroform extraction method of Chomczynski and Sacchi (35). After air drying, the RNA pellet was dissolved in diethyl pyrocarbonate-treated water and stored at $-70^{\circ} \mathrm{C}$. The RNA concentration was determined spectrophotometrically. The yield of total RNA from 5-10 mg of tissue was approximately $10-20 \mu \mathrm{g}$. The quality of the RNA was checked, except in the case of the biopsy specimens (which were too small and in any case had only been stored for up to 6 mo at $-70^{\circ} \mathrm{C}$ ), by electrophoresis of samples (denatured by heating for 5 min at $65^{\circ} \mathrm{C}$ ) on $1 \%$ agarose gels in $0.086 \mathrm{M}$ Tris, $0.09 \mathrm{M}$ borate, 1.9 mM EDTA, pH 8.4 (TBE buffer), containing $0.1 \mu \mathrm{g} / \mathrm{mL}$ ethidium bromide. Only samples with intact $28 \mathrm{~S}$ and 18S RNA were used.

PCR primers. Specific oligonucleotide primers corresponding to the sequences of each gene transcript were designed from the published human cDNA sequences (Table 1) $(11,14,36-38)$. These sequences were designed to span at least one intron by using, when available, published gene structure information or by checking genomic DNA for amplification, so that the PCR product from the mRNA could be distinguished from that of genomic DNA. The sequences were shown to be unique to each gene transcript when checked against the Gen-

Table 1. Oligonucleotide primers used in RNA PCR*

\begin{tabular}{|c|c|c|c|}
\hline Gene & $\begin{array}{l}\text { Position in } \\
\text { cDNA }\end{array}$ & Sequence & $\begin{array}{l}\text { RNA PCR } \\
\text { product }\end{array}$ \\
\hline \multirow[t]{2}{*}{ LPH } & $5454-5476$ & 5' TAC AGT GAC CCT TCT CTG CCA AG 3' & $309 \mathrm{bp}$ \\
\hline & $5741-5763$ & $5^{\prime}$ GGC TTC GTT GTG TTT TCC CTT GC $3^{\prime}$ & \\
\hline \multirow[t]{2}{*}{ SI } & $8-30$ & $5^{\prime}$ GCA GCC TTA TCC AAG TCT GGT AC 3 ' & $216 \mathrm{bp}$ \\
\hline & $203-224$ & $5^{\prime}$ AGT CAC ACG AGT AGT AGC TGG AG $3^{\prime}$ & \\
\hline \multirow[t]{2}{*}{ DPPIV } & $716-739$ & $5^{\prime}$ CCT TCT ACT CTG ATG AGT CAC TGC $3^{\prime}$ & $311 \mathrm{bp}$ \\
\hline & $1004-1027$ & $5^{\prime}$ GTG CCA CTA AGC AGT TCC ATC TTC $3^{\prime}$ & \\
\hline \multirow[t]{2}{*}{ SGLT1 } & $10-31$ & $5^{\prime}$ CAT GGA CAG TAG CAC CTG GAG C $3^{\prime}$ & $636 \mathrm{bp}$ \\
\hline & $624-646$ & 5' CAG CAT GAT CAC CGT CTG CAA GG $3^{\prime}$ & \\
\hline \multirow[t]{2}{*}{ CA1 } & $1045-1119$ & 5' ATG GAG CAA GCT GTA TCC CAT TGC C $3^{\prime}$ & $319 \mathrm{bp}$ \\
\hline & $1339-1364$ & $5^{\prime}$ GAA CCA TGC TCA TTT GTA CTG CCC C $3^{\prime}$ & \\
\hline
\end{tabular}

* LPH, lactase-phlorizin hydrolase; SI, sucrase-isomaltase; DPPIV, dipeptidyl peptidase IV; SGLT1, $\mathrm{Na}^{+}$-dependent glucose transporter; CA1, carbonic anhydrase 1 . 
Bank and EMBL databases. The oligonucleotides were synthesized on a DNA synthesizer (ABI 391 PCRMATE, Applied Biosystems, Foster City, CA).

RNA PCR method. Reverse transcription was usually conducted on 5-10 $\mu \mathrm{g}$ of RNA to carry out multiple PCR reactions. However, for the sake of simplicity, the quantities of reagents for $1 \mu \mathrm{g}$ of RNA are given below: The quantities are given in moles of reagents added as well as molarity $(\mathrm{M}$ or $\mathrm{mol} / \mathrm{L})$ to allow the method to be followed more easily.

Total RNA $(1 \mu \mathrm{g})$ in $5 \mu \mathrm{L}$ of diethyl pyrocarbonatetreated water was denatured at $95^{\circ} \mathrm{C}$ for $5 \mathrm{~min}$. The reverse transcription was carried out by adding $5.2 \mathrm{nmol}$ of each dNTP (final concentration $=260 \mu \mathrm{M}$ or 260 $\mu \mathrm{mol} / \mathrm{L}$ ), $400 \mathrm{pmol}$ of random hexamers (Pharmacia, St. Albans, UK) or $50 \mathrm{pmol}$ of the appropriate specific primer, and $400 \mathrm{U}$ of M-MLV reverse transcriptase (GIBCO BRL, Scotland, UK), $2 \mu \mathrm{L}$ of $10 \times$ Taq DNA polymerase buffer $(500 \mathrm{mM} \mathrm{KCl}, 15 \mathrm{mM} \mathrm{MgCl}, 1 \%$ Triton X-100, 100 mM Tris-HCl, pH 8.8; Promega, Madison, WI), and water to a final volume of $20 \mu \mathrm{L}$. The reaction was incubated at $42^{\circ} \mathrm{C}$ for $60 \mathrm{~min}$ and stopped by heating at $95^{\circ} \mathrm{C}$ for $5 \mathrm{~min}$.

The PCR assay was then performed by adding $10 \mu \mathrm{L}$ of this RT mix, equivalent to $0.5 \mu \mathrm{g}$ of starting RNA, to 90 $\mu \mathrm{L}$ of a standard PCR mix containing $18 \mathrm{nmol}$ of each dNTP (thus adjusting each dNTP to a final concentration of $206 \mu \mathrm{M}), 50 \mathrm{pmol}$ of each of the specific primers, $9 \mu \mathrm{L}$ of Promega Taq DNA polymerase buffer, and $2 \mathrm{U}$ of Promega Taq polymerase. The amplification step in each case comprised 25 cycles of denaturation at $94^{\circ} \mathrm{C}$ for $30 \mathrm{~s}$, annealing at $52^{\circ} \mathrm{C}$ for $40 \mathrm{~s}$, and extension at $70^{\circ} \mathrm{C}$ for $60 \mathrm{~s}$ in a thermal reactor (Hybaid Limited, Middlesex, UK). Control reactions were routinely conducted in which the reverse transcriptase was omitted to test for genomic DNA amplification, and additional controls without template were conducted as another test for contamination. Twenty $\mu \mathrm{L}$ of the PCR products were subjected to electrophoresis in $2 \%$ agarose gels $(20 \times 25 \mathrm{~cm})$ in TBE buffer containing $0.1 \mu \mathrm{g} / \mathrm{mL}$ ethidium bromide (in the gel only) and photographed using Polaroid 665 film. The identity of the PCR products was in each case confirmed by probing with a specific probe or cutting with informative restriction enzymes (data not shown).

\section{RESULTS}

Optimization of the RNA PCR method for quantitation. A number of experiments were conducted that were designed to optimize the reverse transcription step. In an early experiment, Taq DNA polymerase buffer (Promega) was compared with the reverse transcriptase buffer supplied with the M-MLV reverse transcriptase (GIBCO BRL). Because the reverse transcription worked just as well in the Taq polymerase buffer, this was used in all the subsequent experiments. The effect of varying the concentrations of dNTP, reverse transcriptase (GIBCO BRL), and both the random and specific primers on the amount of cDNA synthesized was monitored by PCR in a series of experiments in which the number of cycles of amplification were varied.

The concentrations of each of the dNTP were varied from 260 to $1300 \mu \mathrm{M}$ (final concentration) without changing the amount of RNA used ( $1 \mu \mathrm{g}$ per $20 \mu \mathrm{L}$ of RT mix). There was no increase in the efficiency of the reaction with increasing nucleotide concentration, but rather there was significant inhibition at concentrations higher than $750 \mu \mathrm{M}$. Similarly, the reverse transcription was also inhibited when more than $600 \mathrm{U}$ of M-MLV reverse transcriptase (GIBCO BRL) per $20 \mu \mathrm{L}$ of RT mix were used. The amount of cDNA produced increased with increasing concentration of random hexamers up to 160 $\mathrm{pmol} / \mu \mathrm{g}$ RNA (Fig. 1). In practice, the amount of random hexamers used in the RT mix (400 pmol/ $\mu \mathrm{g} \mathrm{RNA}$ ) is in great excess, but this does not affect the specificity of the PCR and gives a similar amount of PCR product as 50 $\mathrm{pmol} / \mu \mathrm{g}$ RNA of specific primers (data not shown).

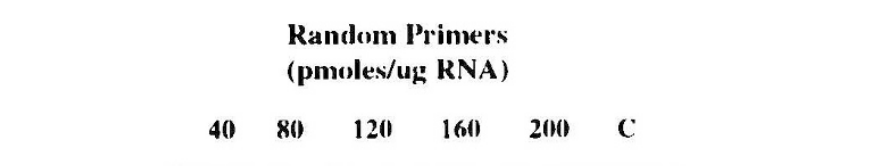

$206 \mathrm{bp}$
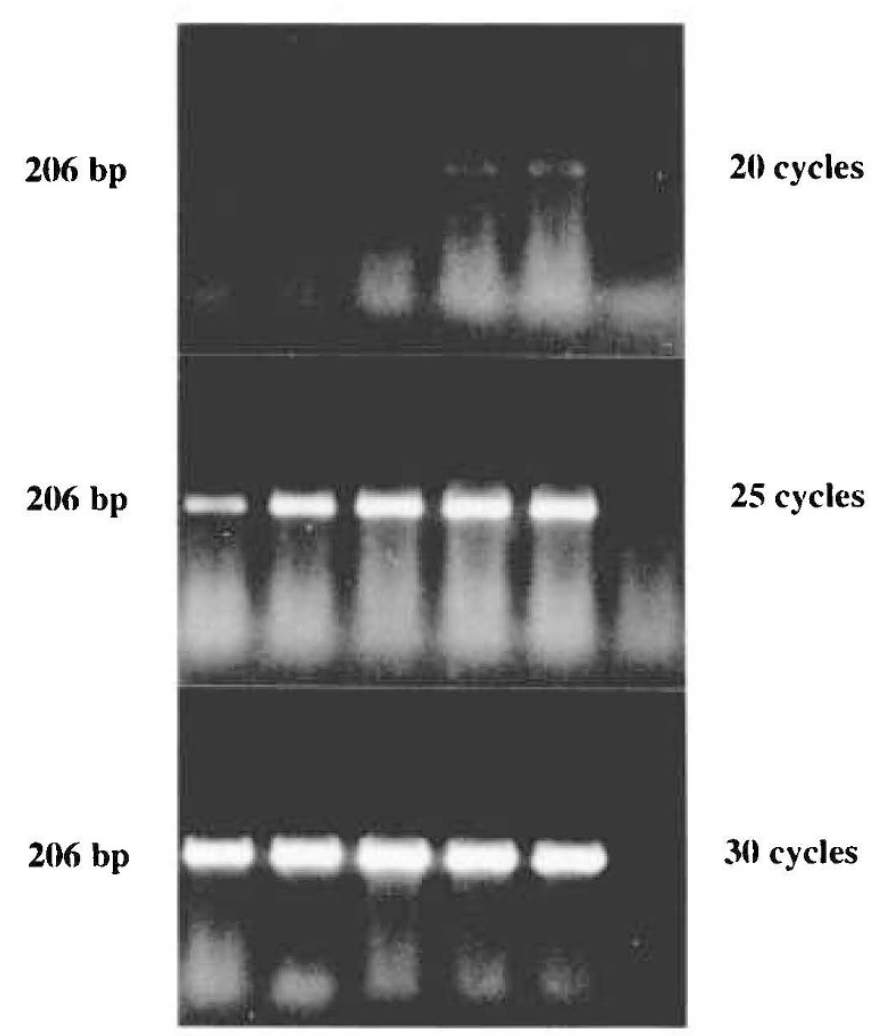

Figure 1. The effect of random primer concentration on the efficiency of the reverse transcription step. The reverse transcription was conducted using total RNA from fetal small intestine with 40,80, 120, 160, or $200 \mathrm{pmol}$ of primer per $1 \mu \mathrm{g}$ of total RNA in the otherwise standard reverse transcription mix and monitored by PCR amplification of the cDNA for 20,25 , and 30 cycles using primers specific for sucraseisomaltase. The control lane shows the result of conducting the transcription step without reverse transcriptase (200 pmol of primer). The negative control without template is not shown. Note that at 30 cycles of amplification the reaction is reaching the saturation and the difference between the reverse transcriptions is no longer evident. 
To calibrate the PCR process, varying amounts of cDNA (corresponding to $0.1-3 \mu \mathrm{g}$ of starting RNA) were tested using the standard PCR reaction as described in Methods. For each of the PCR primers reported here, it was shown that at 25 cycles the amount of PCR product was linearly related to the amount of total starting RNA within the range $0.1-1.0 \mu \mathrm{g}$ and saturated thereafter $(2.0$ $\mu \mathrm{g}$ of starting total RNA) (Fig. 2). The reaction was also no longer linear after 30 cycles, even when $0.5 \mu \mathrm{g}$ of starting total RNA was used (data not shown). Independent PCR reactions conducted from the same cDNA gave very similar quantities of product (Fig. 2). Repeat RNA specimens from the same pieces of tissue also gave very similar results, although small day-to-day variations in the reverse transcription were occasionally seen.

Application of the RNA PCR method to study tissue and developmental distribution of lactase, sucrase-isomaltase, dipeptidyl peptidase $\mathrm{IV}$, and $\mathrm{Na}^{+}$-dependent glucose transporter $\boldsymbol{m R N A}$. A preliminary screen of the tissue distribution of lactase, sucrase-isomaltase, dipeptidyl peptidase IV, and $\mathrm{Na}^{+}$-dependent glucose transporter mRNA was followed by a much more detailed analysis of the expression of these transcripts in the intestine. Some typical results are shown in Figures 3 and 4.

Lactase mRNA was not detected in any of the nonintestinal tissues tested, which included heart, lung, liver, kidney, and spleen from adults and placenta, brain, muscle, thymus, stomach, thyroid, and adrenals from fetuses. Some of the results are presented in Figure 3. It was present at high levels in the small intestine (both duodenum and jejunum) of the lactase-persistent adults (Fig. 4A, lanes 5-8). The results of our analysis of the nonpersistent adults will be reported elsewhere (39). Lactase mRNA was present at much lower levels in all the fetal small intestine samples (Fig. $4 A$, lanes $1-4$ ) with

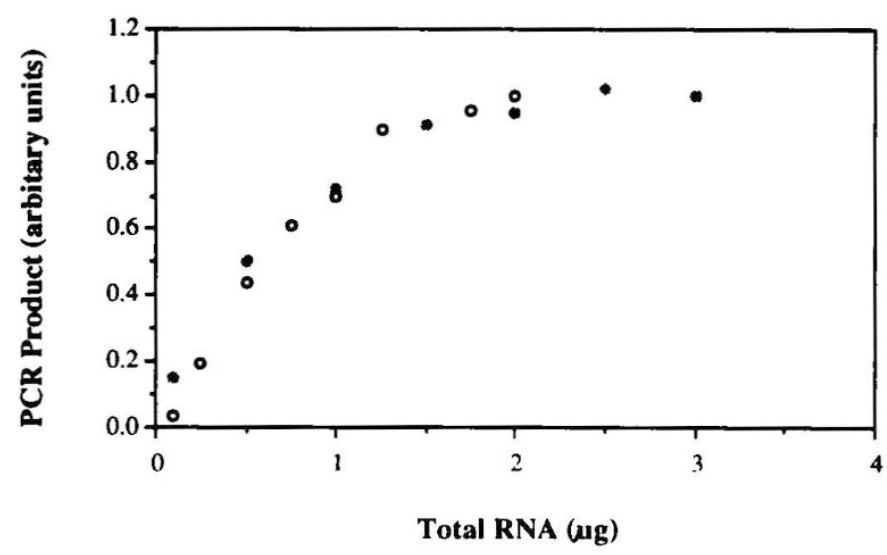

Figure 2. Titration curve showing the quantitative relationship be tween the amount of total RNA transcribed and the amount of PCR product. cDNA reverse transcribed from 0.1 to $3 \mu \mathrm{g}$ of total RNA from fetal small intestine was subjected to 25 cycles of PCR amplification using primers specific for sucrase-isomaltase. The relative amount of PCR product was determined by scanning the photographic negatives with an Ultralaser Scanner XL (LKB, Bromma, Sweden) and the area of each peak was calculated and presented as arbitrary units. The points represent results of two different experiments using the same cDNA. Open circles, experiment 1; stippled circle, experiment 2. very little difference in the level of expression from 9 to 18 wk of gestation. It was also present in trace amounts in the fetal colon (Fig. $4 B$, lanes 1-4) but was not detectable at all in the adult colon samples (Fig. 4B, lanes 5-8).

Sucrase-isomaltase mRNA was not detected in any of the nonintestinal tissues under the conditions used (Fig. 3 ), but was detected at high levels in both the fetal and adult small intestine (Fig. $4 A$ ) and in fetal colon (both proximal and distal) (Fig. 4B, lanes 1-4). It is also expressed in adult colon, although at a slightly lower level than in the fetuses (Fig. 4B, lanes 5-8).

Dipeptidyl peptidase IV mRNA was detected in all the tissues examined (Fig. 3). Similar levels of this mRNA were found in the small intestine of both the fetuses and adults (Fig. 4A). Significant amounts of dipeptidyl peptidase IV mRNA were also detected in both the fetal (proximal and distal) and adult colon (Fig. 4B).

The $\mathrm{Na}^{+}$-dependent glucose transporter mRNA was detected in adult colon (Fig. $4 B$, lanes 5-8) and in the small intestine of fetuses and adults (Fig. $4 A$ ) but not in fetal colon (Fig. $4 B$, lanes 1-4) or any other tissues studied (Fig. 3) under the conditions used here.

Carbonic anhydrase $1 \mathrm{mRNA}$ was detected at high levels in all the adult colon specimens (Fig. 4B, lanes 5-8) but was present at much lower levels or was undetectable in the distal and proximal colon preparations from the fetuses (Fig. $4 B$, lanes $1-4$ ) and could not be detected at all in any of the small intestine samples under the conditions used (Fig. $4 A$ ).

\section{DISCUSSION}

We describe here the conditions that we have used, and their validation, for a simple PCR method for the measurement of mRNA. A semiquantitative assay was devised by optimizing the reverse transcription and adjusting the subsequent $\mathrm{PCR}$ process by limiting both the starting RNA and the number of cycles of amplification. The sensitivity of the method means that many analyses can be completed on the same 5-10 mg of tissue. Although the individual PCR assays need to be calibrated, this general method should prove useful for the analysis of other genes in similar small diagnostic specimens. In our hands, the method is preferable to the use of RNase protection assays (40) because it is more sensitive, quicker, and more straightforward; it does not require radioactivity; and it is not necessary to have access to the appropriate clones. Although the method does not allow absolute quantitation of the transcripts (because they differ in length and sequence), it does provide a simple way of examining tissue distribution. It is particularly convenient for studying tissue-to-tissue variation in relative expression of a number of different transcripts. The analysis of multiple transcripts in one assay also provides a powerful internal control for the quality of the specimens and is useful in cases such as described here in which there is variation in the proportion of particular cell types in a specimen. 



Figure 3. The tissue distribution of lactase-phlorizin hydrolase $(L P H)$, sucrase-isomaltase (SI), dipeptidyl peptidase IV (DPPIV), and the $\mathrm{Na}^{+}$-dependent glucose transporter (SGLT1) mRNA as assessed by RNA PCR. The tissues are from adults unless otherwise specified. The adult small intestine sample was a full-thickness specimen from the midjejunum. The reverse transcriptions for each tissue were carried out in a single experiment and the gene-specific amplifications were all conducted using these same cDNA. $M W$ denotes the molecular weight markers (1 kb DNA ladder, GIBCO BRL).

Our results on the expression of lactase mRNA in the small intestine correlate reasonably well with those reported for the distribution of the enzyme activity and the presence of the lactase protein. Lactase activity has, for example, been shown to be very low before the 24 th wk of gestation $(5,7,8,18)$, and a low level of lactase mRNA was observed in the recent study by Villa et al. (18). It is of interest that very low but detectable levels of lactase mRNA were also found in fetal colon, because conflicting results have been obtained for the expression of lactase protein in fetal colon. Lacroix et al. (33) and Raul et al. (41) failed to detect any lactase activity in 8- to 30 -wk fetal colon, and no lactase protein was detected by
Zweibaum et al. (28) in 16- to 20 -wk fetal colon. This is in contrast to the work by Dahlqvist and Lindberg (8) and Menard and Pothier (42), who reported low lactase activity in fetal colon in the period they studied (11-23 wk). It seems likely that the level of expression of the protein is such that it is at the borderline of detection. Lactase mRNA was not detected at all in the adult colon samples or in the nonintestinal tissues tested.

Sucrase-isomaltase mRNA was detected in all the intestinal samples tested but was not detected in nonintestinal tissue under the conditions used here, despite the fact that we had previously shown low levels of a sucrase-isomaltase-like protein in adult lung, adrenal, mus- 


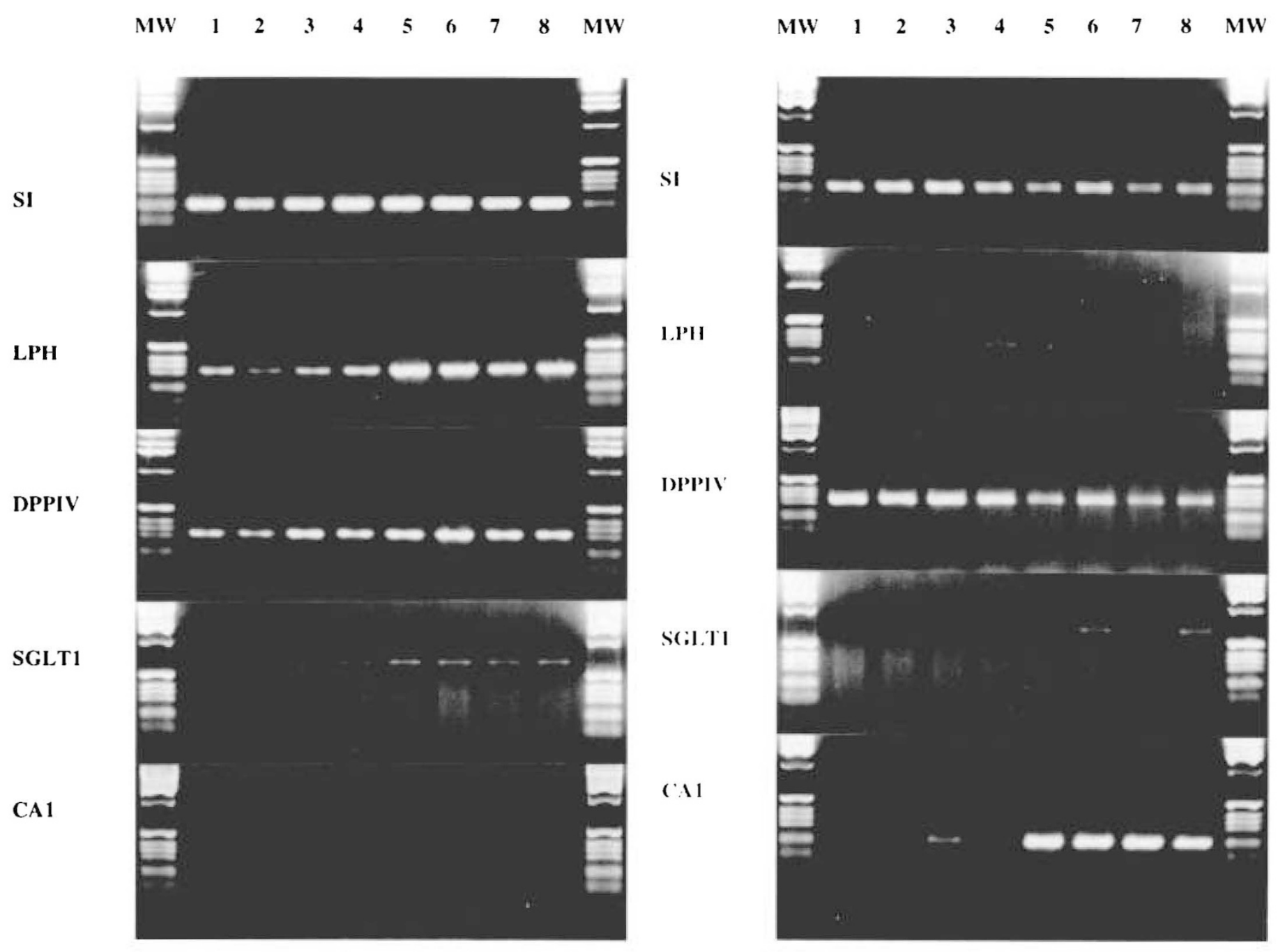

Figure 4. Expression of multiple mRNA in representative samples of human small and large intestine. $A$, Small intestine: lanes $1-4$, fetal (13, 14, 14 , and $15 \mathrm{wk}$ ); lanes 5 and 6 , adult full-thickness distal jejunum; lanes 7 and 8 , adult duodenum (mucosal biopsy). B, Colon: lanes $1-4$, fetal proximal colon $(10,10,11$, and $12 \mathrm{wk})$; lanes $5-8$, adult distal colon. $M W$ denotes the molecular weight markers (1 kb DNA ladder, GIBCO BRL). $S I$, sucrase-isomaltase; $L P H$, lactase-phlorizin hydrolase; $D P P I V$, dipeptidyl peptidase IV; $S G L T I, \mathrm{Na}^{+}$-dependent glucose transporter; $C A I$, carbonic anhydrase 1.

cle (43), and bladder (unpublished data). In contrast and perhaps more surprising, however, was the relatively high level of sucrase-isomaltase mRNA in the adult colon samples tested. These same samples showed virtually undetectable sucrase activity (Rousset M, Zweibaum A, unpublished data). Although there is now general agreement that sucrase-isomaltase is expressed at low levels in normal adult colon $(26,27,32,44,45)$, there is clearly substantially less protein and enzyme activity than in the small intestine and than might have been expected from the levels of mRNA that we have observed in this study. High levels of expression of the sucrase-isomaltase protein in fetal colon between 8 and 30 wk of gestation are well documented $(28,31-33)$, and this is consistent with the high mRNA levels observed here. However, we have also noted that the level of protein and enzyme activity in fetal colon appears to be somewhat less than that in the small intestine (46) (Wang Y, Swallow DM, unpublished observations) and perhaps less than might have been expected from the level of mRNA. These observations may suggest that posttranscriptional events are in part regulating the expression of sucrase-isomaltase in the colon, or it may simply mean that the protein present on the lumen of the colon is rapidly degraded. It would be of some interest to reexamine the expression of sucraseisomaltase mRNA in colon, late in gestation and in babies, in relation to the enzyme activity, but such material is unfortunately very hard to obtain.

We have found that dipeptidyl peptidase IV mRNA is expressed in all the human tissues we tested, which is consistent with the wide tissue and cellular expression observed at the level of the protein in the rat (15). Dipeptidyl peptidase IV mRNA, similar to sucrase-isomaltase, is expressed at high levels in fetal small intestine, and this 
is consistent with the reports of high enzyme activity at this stage of development (13). The high level of dipeptidyl peptidase IV mRNA found in the colon, as in the case of sucrase-isomaltase, is somewhat unexpected in view of the rather low levels of the enzyme and protein observed in some studies $(27,28)$ but is consistent with the immunostaining results of Gorvel et al. (32); the combined results are suggestive of tissue- or cell-specific differences in mRNA or protein processing.

The mRNA for the $\mathrm{Na}^{+}$-dependent $\mathrm{D}$-glucose cotransporter was detected in both the fetal and adult human small intestine, which is in keeping with previous functional and molecular evidence concerning the expression of this transporter $(4,47)$. However, it is rather surprising that the same message was detected at high levels in the adult colon but not in fetal colon, and the significance of this is not clear.

In this study, we have confirmed previous observations that the "colonic" carbonic anhydrase 1 transcript is expressed predominantly in adult colon and at much lower levels in fetal colon but is not detectable in either fetal or adult small intestine (34), and it is quite different in its pattern of expression from the enterocytic markers. However, these brush-border markers also differ from one another, indicating that the molecular mechanisms regulating their expression are very complex and probably involve multiple transcription factors. In particular, even sucrase-isomaltase and lactase, which share the same restricted tissue distribution, show marked cellular and developmental differences in their steady state mRNA levels. This is consistent with the fact that marked differences have been noted in other species (1) and also with the fact that there appears to be very little similarity between the two promoters $(36,48,49)$.

The RNA PCR method described here is proving invaluable for the analysis of the expression of these enzymes in biopsy specimens taken from lactase-persistent and -nonpersistent adults (39) and from children with malabsorption and should be useful to other investigators studying gene expression.

Acknowledgments. The authors thank all those who have helped with advice, supply of samples, and preparation of oligonucleotides, in particular, Dr. Sue Povey, Dr. Cathy Abbott, John Attwood, M. Bewick, Dr. Vanya Braga, Ira Islam, Dr. Ruth March, Dr. Josef Neu, Dr. Virginia Sams, Dr. Martin Sarner, Dr. Jane Sowden, Dr. Leslie Wong, Magdi Yacoub, and Dr. Alain Zweibaum.

\section{REFERENCES}

1. Henning SJ 1986 Functional development of the gastrointestinal tract. In: Johnson LR (ed) Physiology of the Gastrointestinal Tract. Raven Press, New York, pp 285-300

2. Karasov WH, Diamond JM 1986 Adaptation of intestinal nutrient transport. In: Johnson LR (ed) Physiology of the Gastrointestinal Tract. Raven Press, New York, pp 1489-1498

3. Semenza G 1986 Anchoring and biosynthesis of stalked brush-border membrane-proteins: glycosidases and peptidases of enterocytes and renal tubuli. Annu Rev Cell Biol 2:255-313

4. Wright EM 1993 The intestinal $\mathrm{Na}^{+}$/glucose cotransporter. Annu Rev Physiol 55:575-589
5. Auricchio S, Rubino A, Murset G 1965 Intestinal glycosidase activities in the human embryo, fetus and newborn. Pediatrics 35:944-945

6. Antonowicz I, Chang SK, Grand RJ 1974 Development and distribution of lysosomal enzymes and disaccharidases in human fetal intestine. Gastroenterology 67:51-58

7. Antonowicz I, Lebenthal E 1977 Developmental pattern of small intestinal enterokinase and disaccharidase activities in the human fetus. Gastroenterology 72:1299-1303

8. Dahlqvist A, Lindberg T 1966 Development of the intestinal disaccharidase and alkaline phosphatase activities in the human foetus. Clin Sci 30:517-528

9. Newcomer AD, McGill DB 1966 Clinical importance of lactase deficiency. N Engl J Med 310:42-43

10. Smith MW 1985 Expression of digestive and absorptive function in differentiating enterocytes. Annu Rev Physiol 47:247-260

11. Mantei N, Villa M, Enzler T, Wacker H, Boll W, James P, Hunziker W, Semenza G 1988 Complete primary structure of human and rabbit lactasephlorizin hydrolase: implications for biosynthesis, membrane anchoring and evolution of the enzyme. EMBO J 7:2705-2713

12. Buller HA, Kothe M, Goldman DA, Grubman SA, Sasak WV, Matsudaira PT, Montgomery RK, Grand RJ 1990 Coordinate expression of lactatephlorizin hydrolase mRNA and enzyme levels in rat intestine during development. J Biol Chem 265:6978-6983

13. Auricchio S, Stellato A, De Vizia B 1981 Development of brush border peptidases in human and rat small intestine during fetal and neonatal life. Pediatr Res 15:991-995

14. Darmoul D, Lacasa M, Baricault L, Marguet D, Sapin C, Trotot P, Barbat A, Trugnan G 1992 Dipeptidyl peptidase IV (CD26) gene expression in enterocyte-like colon cancer cell lines HT-29 and Caco-2. Cloning of the complete human coding sequence and changes of dipeptidyl peptidase IV mRNA levels. J Biol Chem 267:4824-4833

15. Hartel S, Gossran R, Hanski C, Reutter W 1988 Dipeptidylpeptidase IV (DPPIV) in rat organs: comparison of immunohistochemistry and activity. Histochemistry 89:151-161

16. Traber PG, Yu L, Wu GD, Judge TA 1992 Sucrase-isomaltase gene expression along crypt-villus axis of human small intestine is regulated at level of mRNA abundance. Am J Physiol 262:G123-G130

17. Sebastio G, Hunziker W, O'Neill B, Malo C, Menard D, Auricchio S, Semenza G 1987 The biosynthesis of intestinal sucrase-isomaltase in human embryos is most likely controlled at the level of transcription. Biochem Biophys Res Commun 149:830-839

18. Villa M, Menard D, Semenza G, Mantei N 1992 The expression of lactase enzymatic activity and mRNA in human fetal jejunum. Effect of organ culture and of treatment with hydrocortisone. FEBS Lett 301:202-206

19. Keller P, Zwicker E, Mantei N, Semenza G 1992 The levels of lactase and of sucrase-isomaltase along the rabbit small intestine are regulated both at the mRNA level and post-translationally. FEBS Lett 313:265-269

20. Freund JN, Duluc I, Raul F 1991 Lactase expression is controlled differently in the jejunum and ileum during development in rats. Gastroenterology 100:388-394

21. Freeman TC, Collins AJ, Heavens RP, Tivey DR 1993 Genetic regulation of enterocyte function: a quantitative in situ hybridisation study of lactasephlorizin hydrolase and $\mathrm{Na}^{+}$-glucose cotransporter $\mathrm{mRNAs}$ in rabbit small intestine. Eur J Physiol 422:570-576

22. Traber PG 1990 Regulation of sucrase-isomaltase gene expression along the crypt-villus axis of rat small intestine. Biochem Biophys Res Commun 173:765-773

23. Chelly J, Kaplan J-C, Maire P, Gautron S, Kahn A 1988 Transcription of the dystrophin gene in human muscle and non-muscle tissues. Nature 333:858860

24. Frohman MA, Dush MK, Martin GR 1988 Rapid production of full-length cDNAs from rare transcripts: amplification using a single gene-specific oligonucleotide primer. Proc Natl Acad Sci USA 85:8998-9002

25. Gilliland G, Perrin S, Bunn HF 1990 Competitive PCR for quantitation of mRNA. In: Innis MA, Gelfand DH, Sninsky JJ, White TJ (eds) PCR Protocols: A Guide to Methods and Applications. Academic Press, New York, pp 60-69

26. Quaroni A, Nichols BL, Quaroni E, Hurst K, Herrera L, Weiser MM, Hamilton SR 1992 Expression and different polarity of aminopeptidase $N$ in normal human colonic mucosa and colonic tumors. Int J Cancer 51:404-411

27. Real FX, Rosa VM, Xu M, De Bolos C 1992 Intestinal brush-borderassociated enzymes: co-ordinated expression in colorectal cancer. Int J Cancer 51:173-181

28. Zweibaum A, Hauri H-P, Sterchi E, Chantret I, Haffen K, Bamat J, Sordat B 1984 Immunohistological evidence, obtained with monoclonal antibodies, of small intestinal brush border hydrolases in human colon cancers and foetal colons. Int J Cancer 34:591-598

29. Wiltz O, O'Hara CJ, Steele GD, Mercurio AM 1991 Expression of enzymatically active sucrase-isomaltase is a ubiquitous property of colon adenocarcinomas. Gastroenterology 100:1266-1278

30. Buller HA, Rings EHHM, Montgomery RK, Sybicki MA, Grand RJ 1989 Suckling rat colon synthesizes and processes active lactase-phlorizin hydrolase immunologically identical to that from jejunum. Pediatr Res 26:232-236

31. Foltzer-Jourdainne C, Kedinger M, Raul F 1989 Perinatal expression of brush border hydrolases in rat colon: hormonal and tissue regulations. Am J Physiol 257:G496-G504 
32. Gorvel JP, Ferrero A, Chambraud L, Rigal A, Bonicel J, Maroux S 1991 Expression of sucrase-isomaltase and dipeptidylpeptidase IV in human small intestine and colon. Gastroenterology 101:618-625

33. Lacroix B, Kedinger M, Simon-Assmann P, Rousset M, Zweibaum A 1984 Developmental pattern of brush border enzymes in the human fetal colon. Correlation with some morphogenetic events. Early Hum Dev 9:95-103

34. Sowden J, Leigh S, Talbot I, Delhanty J, Edwards Y 1993 Expression from the proximal promoter of the carbonic anhydrase-1 gene as a marker for differentiation in colon epithelia. Differentiation 53:67-74

35. Chomczynski P, Sacchi N 1987 Single-step method of RNA isolation by acid guanidinium thiocyanate-phenol-chloroform extraction. Anal Biochem 162:156-159

36. Chantret I, Lacasa M, Chevalier G, Ruf J, Islam I, Mantei N, Edwards Y, Swallow D, Rousset M 1992 Sequence of the complete cDNA and the 5' structure of the human sucrase-isomaltase gene: possible homology with a yeast glucoamylase. Biochem J 285:915-923

37. Hediger MA, Turk E, Wright EM 1989 Homology of the human intestina $\mathrm{Na}^{+}$/glucose and E. coli Na/proline cotransporters. Proc Natl Acad Sci USA $86: 5748-5752$

38. Lowe N, Brady HJ, Barlow JH, Sowden JC, Edwards M, Butterworth PHW 1990 Structure and methylation patterns of the gene encoding human carbonic anhydrase I. Gene 93:277-283

39. Harvey CB, Wang Y, Hughes LA, Swallow DM, Thurrell WP, Barton R, Sarner M 1994 Studies on the expression of intestinal lactase in differen individuals. Gut (in press)

40. Rea TJ, DeMattos RB, Rape ME 1993 Hepatic expression of genes regulating lipid metabolism in rabbits. J Lipid Res 34:1901-1910
41. Raul F, Lacroix B, Aprahamian M 1986 Longitudinal distribution of brush border hydrolases and morphological maturation in the intestine of the preterm infant. Early Hum Dev 13:225-234

42. Menard D, Pothier P 1987 Differential distribution of digestive enzymes in isolated epithelial cells from developing human fetal small intestine and colon. J Pediatr Gastroenterol Nutr 6:509-516

43. Swallow DM, Green FR, Sams V 1988 Biochemical and molecular genetics of human sucrase-isomaltase. In: Lentze MJ, Sterchi EE (eds) Mammalian Brush Border Membrane Proteins. Georg Thieme Verlag, New York, pp $52-62$

44. Beaulieu J-F, Weiser MA, Herrera L, Quaroni A 1990 Sucrase-isomaltase in adult human colon and in colon polyps. Gastroenterology 98:1467-1477

45. Czernichow B, Simon-Assmann P, Kedinger M, Arnold C, Parache M, Marescaux J, Zweibaum A 1989 Sucrase-isomaltase expression and enterocytic ultrastructure of human colorectal tumours. Int J Cancer 44:238-244

46. Triadou N, Zweibaum A 1985 Maturation of sucrase-isomaltase complex in human fetal small and large intestine during gestation. Pediatr Res 19:136138

47. Semenza G, Kessler M, Schmidt U, Venter JC, Fraser CM 1985 The smallintestinal sodium-glucose cotransporter(s). Ann NY Acad Sci 456:83-96

48. Traber PG, Wu GD, Wang W 1992 Novel DNA-binding proteins regulate intestine-specific transcription of the sucrase-isomaltase gene. Mol Cell Biol 12:3614-3627

49. Lloyd M, Mevissen G, Fischer M, Olsen W, Goodspeed D, Genini M, Boll W, Semenza G, Mantei N 1992 Regulation of intestinal lactase in adult hypolactasia. J Clin Invest 89:524-529 